University of Nebraska - Lincoln

DigitalCommons@University of Nebraska - Lincoln

Sociology Department, Faculty Publications

Sociology, Department of

1986

\title{
Multiple Dimensions of the Moral Majority Platform: Shifting Interest Group Coalitions
}

Helen A. Moore

University of Nebraska-Lincoln, hmoore1@unl.edu

Hugh P. Whitt

University of Nebraska-Lincoln, hwhitt1@unl.edu

Follow this and additional works at: https://digitalcommons.unl.edu/sociologyfacpub

Part of the Sociology Commons

Moore, Helen A. and Whitt, Hugh P., "Multiple Dimensions of the Moral Majority Platform: Shifting Interest Group Coalitions" (1986). Sociology Department, Faculty Publications. 105.

https://digitalcommons.unl.edu/sociologyfacpub/105

This Article is brought to you for free and open access by the Sociology, Department of at DigitalCommons@University of Nebraska - Lincoln. It has been accepted for inclusion in Sociology Department, Faculty Publications by an authorized administrator of DigitalCommons@University of Nebraska - Lincoln. 


\title{
Multiple Dimensions of the Moral Majority Platform: Shifting Interest Group Coalitions
}

\author{
Helen A. Moore \\ Hugh P. Whitt \\ University of Nebraska-Lincoln \\ Corresponding author - Helen A . Moore, Department of Sociology, \\ University of Nebraska-Lincoln, Lincoln Nebraska 68588-0324
}

\begin{abstract}
The issues raised by the New Political Right and the Moral Majority have overlapped in recent political history. Researchers have assumed that a single additive scale across conservative issues can identify the base of support for the Moral Majority as an organization. We examine general support for the Moral Majority separately from support for six specific issues: teaching creationism, voluntary public school prayer, military defense spending, gun control, pornography and abortion. Data are from a 1982 random sample of adult respondents from Nebraska ( $\mathrm{N}=1907)$.

Overall, support for the Moral Majority organization is low. Discriminant analysis identifies fundamentalist and evangelical religious affiliation and Biblical literalism as independent predictors of support for the Moral Majority per se. Education increases knowledge of the organization, but does not influence support for it. Respondents with high income levels are more likely to support the Moral Majority organization. These findings contradict theories of both status politics and cultural fundamentalism.

Support for the six specific platform items also varies considerably and is affected by religious conservatism and, independently, by other attitudinal and demographic indicators including age, sex, income, rural residence, education and perception of declining economic conditions. These patterns do not entirely fit the predictions of status politics or cultural fundamentalism theories. Rather, they provide evidence that distinct coalitions form on specific issues. Our conclusion is that a simple additive index of support for the Moral Majority masks these differences and oversimplifies complex patterns of coalitions in the religio-political arena.
\end{abstract}

Previous studies of the Moral Majority have relied heavily upon theories of status politics and cultural fundamentalism. Both positions, as we will discuss in detail, assume that conservatism cuts across issues. Indeed, the status politics position suggests that those who are economically or socially dispossessed should be opposed to any threat to tradi- 
tionalism, while the cultural fundamentalism argument maintains that a single overarching worldview accounts for conservatism on a variety of moral issues.

In contrast, we argue that support for the Moral Majority's sociopolitical positions is confined neither to the dispossessed nor to cultural fundamentalists. Although these theoretical interpretations cannot be rejected out of hand, both explanations neglect shifting coalitions and single issue campaigns. The cultural fundamentalists and the dispossessed may form a stable core of support for the Moral Majority, but each separate issue also has its own separate constituency. Economically, conservatism favors the wealthy rather than the dispossessed. Plowman (1979) argues that the well educated, Catholics, and even feminists may align with the Moral Majority on some issues in its potpourri of"... traditional moral and biblical principles." Catholics, for example, have demonstrated political interests in religious education and abortion (Granberg 1981). Some segments of the women's movement, though bitterly opposed to Falwell's organization and most of its goals, share the Moral Majority's opposition to pornography (Rubin 1984). Defense industries and communities with military bases have economic interests in supporting increased defense spending. The National Rifle Association, supported largely by hunters and hobbyists, agrees with the New Religious Right in opposing gun control legislation (Himmelstein 1983).

Harper and Leicht (1982, 1984; cf. Gannon 1981) argue that the New Religious Right has had less direct political impact than its adherents claim. From this perspective, the swing toward conservatism during the 1980s "... extends far beyond the evangelical camp which is presumed to be the locus of support for the New Religious Right" (Harper and Leicht 1982, p. 1). Indeed, representatives of the political New Right are cited as capitalizing on funding, connections and skills of the "Christian moral voter" (Jorstad 1981, p. 21; quoted in Speer 1984, p. 36). This suggests that major sources of support for conservative political causes lie outside the Moral Majority and indeed beyond the confines of evangelical or fundamentalist Christianity.

Methodologically, researchers have commonly combined scores on several items we have already cited into a single indicator of support for the Moral Majority "platform" (Simpson 1983; Yinger and Cutler 1982). This research strategy assumes that the issues form a unidimensional scale which correlates highly with support for the Moral Majority as an organization and, consequently, with the status politics of specific demographic groups or a generalized cultural fundamentalism. Simpson $(1983,1985)$ presents evidence that a wide range of Moral Majority issue items can be scaled. However, attitudes toward issues may be independent of knowledge of, and attitudes toward, the Moral Majority (cf. Harper and Leicht 1982). Shupe and Stacy $(1982,1983,1984)$ suggest that support for the Moral Majority does not necessarily predict agreement with its stands on the issues.

We separately analyze six issues in three areas which have been researched in the past: (I) public school reforms aimed against secular humanism; (2) themes of patriotism in increased military defense spending and noninterventionist stances on gun control; and (3) moral proscriptions on pornography and abortion. Our specific hypotheses include the following:

1. Support for the Moral Majority as a group will derive primarily from religious conservatism as measured by (a) Biblical literalism, or (b) identification with evangelical or fundamentalist religious groups. 
2. Various interest groups or status groups will align with or disassociate from the Moral Majority stance on specific issues. The pattern will reflect not only the predictions of status politics or cultural fundamentalist frameworks, but will also reveal shifting coalitions.

Beyond these hypotheses, our work is essentially exploratory. Ad hoc political or historical explanations will be brought to bear in interpreting alignments for specific issues. Primarily, we are interested in revealing these shifting patterns and arguing for a multidimensional approach to understanding the political platform of the Moral Majority or the New Religious Right.

\section{The New Political Right and the New Religious Right}

The New Political Right burst on the national scene soon after Watergate. At first primarily secular, the movement was a diffuse coalition of single-issue groups under the aegis of a small number of "core activists" such as Richard Viguerie, Jesse Helms, John T. Dolan and Paul Weyrich (Himmelstein 1983). The positions advocated by the New Right were often consonant with those of religious conservatives. However, evangelical and fundamentalist religious leaders, including Billy Graham and such "televangelists" (Hadden and Swann 1981) as Pat Robertson, were not active in the political realm. These leaders were more concerned with their traditional charge of saving souls and identifying problems of individual morality than with engineering social change. The birth of the Moral Majority in June, 1979 took observers of evangelical and fundamentalist religion by surprise (Hill and Owen 1982; Marty 1985).

Initially, the Moral Majority was a single-issue movement focusing on government interference with the operation of independent Christian schools, particularly in Virginia. Its co-founder and chief spokesperson, Rev. Jerry Falwell, quickly expanded the agenda and forged a strong link between religion and politics aimed at protecting what the organization called the "Christian Bill of Rights" (Brown 1986). His overall strategy has been to work toward governmental policies based upon biblical principles. Many, if not most, of the issues in the expanded Moral Majority "platform" had already been raised by the New Political Right. Researchers have characterized this platform as including such diverse issues as abortion, the equal rights amendment, voluntary school prayer, pornography, homosexuality, secular humanism in schools (including the teaching of evolution and sex education), drug abuse, atheism, gun control, military defense spending, and the protection of Christian school movements (Harper and Leicht 1982; Himmelstein 1983; Yinger and Cutler 1982). The Moral Majority contributed a scriptural justification for conservative politics and promoted the conservative position through techniques of religiopolitical persuasion such as the "Old Time Gospel Hour" on television, direct mailings, and personal appearances by Falwell.

After the 1980 and 1984 national elections, the Moral Majority and the New Right claimed to have placed Ronald Reagan in the White House and removed a number of liberal U.S. Senators and Representatives from office (Gannon 1981). New Right leader Richard Viguerie (1981, p. 3) termed the 1980 election the first "modern conservative landslide." Many defeated politicians agreed with this assessment, and President Reagan 
acknowledged Falwell's political power by consulting with him on the appointment of Supreme Court Justice Sandra Day O'Connor (Hill and Owen 1982).

Conservative religio-political movements of the past have led to the development of theories designed to explain what Lipset and Raab (1978) call the "politics of unreason." More recently, researchers have attempted to apply these theories to the Moral Majority as an organization, with little success. Past difficulties in explaining support for the Moral Majority may be traced to two problems, one methodological, the other theoretical.

The methodological difficulty lies in reliance in past studies upon sets of religio-political issues which presumably tap support for the Moral Majority. Some of these issues do not appear in the Christian Bill of Rights, but are instead a part of the broader New Right platform. Because the New Religious Right and the secular New Right form a loose coalition, the use of these item sets to measure support for the Moral Majority per se has little face validity. Nonetheless, as we review below, the theories guiding most studies assume that right-wing politics cut across issues. Our own thesis is that the radical right is not all of a piece. Coalitions form and reform around particular issues, and those who support the Moral Majority position on one issue may oppose it on another. Thus, one-dimensional explanations are likely to fail. Indeed, Falwell himself discerned the unwieldly and contradictory nature of some positions attributed to him by the media (and, we might add, by social scientists). In January, 1986, he dissolved the Moral Majority and re-constituted it as the Liberty Foundation, precisely because of "distortion by the media" of his issues (Time, January 7, 1986; p. 25).

The theoretical difficulties are more complex. Attempts to explain the "politics of unreason" have generated two predominant frameworks: status politics and cultural fundamentalism.

\section{Status Politics and Cultural Fundamentalism}

Beginning with Seymour Martin Lipset (1963) and Daniel Bell (1963), sociologists and political scientists have argued that right-wing religio-political movements are symbolic responses to status discontent (cf. Gusfield 1966; Lipset and Raab 1978, 1981; Whitt and Nelsen 1975). From this perspective, support for the radical right is centered in the "dispossessed" ( Bell 1962), i.e., groups of people who see their way of life vanishing as a result of modernism in dress, speech, religion, and sexual relations. As Wood and Hughes (1964; cf. Harper and Leicht 1984; Simpson 1985) point out, there are two versions of this argument, one based on economic status and the other on a more Weberian "life style" or "status group" approach.

Lipset emphasized the economic status argument; to him, the real problem is the declining political and economic influence of the "once hads" or the resentment felt by the "never hads" (Lipset and Raab 1978). Such groups go through a process of "status substitution" through which "the cultural trappings of a group stand in for the group and become invested with special significance" ( Lipset and Raab 1978, p. 131).

On the other hand, Gusfield's (1966) analysis of moral or symbolic crusades represents the emphasis on lifestyle as opposed to underlying economic and political motivations. Status politics is not so much a symbolic response to economic and political interests as it is an attempt to buttress a cherished lifestyle against the threat of modernism. Page and Clelland (1978) call this the "politics of life-style concern." 
The status politics argument, in one form or the other, has been used to explain such right-wing movements as the Ku Klux Klan, the John Birch Society, and McCarthyism (Lipset and Raab 1978), the rise of Prohibition (Gusfield 1966) and community campaigns against pornography (Zurcher and Kirkpatrick 1976). If the Moral Majority is a product of status politics, its adherents and those who support its stands should come disproportionately from those groups most threatened by the social changes of the recent past (e.g., urbanization, detente, changes in family structure and sex roles). Demographically, they should be concentrated among the elderly, persons living in rural areas and small towns, and those with lower levels of education and economic attainment. Attitudinally, they should be those who see their lot in life getting worse, their economic prospects deteriorating, or their nation moving toward economic scarcity.

Recent studies (Harper and Leicht 1984; Simpson 1985; Wood and Hughes 1984) have suggested that status politics inadequately explains support for the New Religious Right. This is particularly true of the economic form of the argument. With the exception of education, socioeconomic variables are poor predictors of Moral Majority support (Harper and Leicht 1982, 1984; Tamney and Johnson 1982; Shupe and Stacy 1982, 1983, 1984). Indeed, the Moral Majority gained prominence at a time when fundamentalism was gaining in power and influence. An alternative explanation, favored by Tamney and Johnson (1982), Wood and Hughes (1984) and others, is that support for the Moral Majority stems from cultural and socialization factors and reflects a form of "cultural fundamentalism" (Gusfield 1966; Page and Clelland 1978; Harper and Leicht 1984; Wood and Hughes 1984). Wood and Hughes (1984, p. 89) characterize cultural fundamentalism as involving "adherence to traditional norms, respect for family and religious authority, asceticism and control of impulse." It is "an unflinching and thoroughly moralistic outlook" which ties together various issues of the New Religious Right-alcohol, pornography, and other profamily, decency issues.

The sources of cultural fundamentalism should be found in low levels of education, rural residence, and especially in involvement in conservative and fundamentalist religious groups (Wood and Hughes 1984). The cultural fundamentalism argument suggests that both education and rural residence produce conservative stances because of socialization rather than because of threats to economic and social status.

In brief, we predict that these two theoretical frameworks assume consistency across a range of conservative political issues that may actually attract a variety of coalitions. Single indices of these broad-ranging issues cannot summarize general support for the Moral Majority organization or the New Religious Right.

\section{Data and Method}

Our data were drawn from the 1982 Nebraska Annual Social Indicators Survey. A statewide sample $(\mathrm{N}=1907)$ of non-institutionalized persons aged 18 or above was selected by random digit-dialing procedures and interviewed by telephone (Booth et al. 1980; Moore 1982). Although the interviews covered many aspects of the quality of life, the items of interest for this analysis include: (1) religious preference; (2) demographic variables associated with status politics, cultural fundamentalism and political interest groups; (3) items tapping perceptions of change in economic prospects and the probabil- 
ity of resource shortages in the United States; (4) knowledge of and support for the Moral Majority; (5) attitudes toward issues identified by past researchers as associated with the Moral Majority, including voluntary public school prayer, the teaching of creationism, governmental regulation of pornography, military spending, gun control, and abortion (see Viguerie 1981); and (6) an item designed to measure Biblical literalism as an indicator of religious fundamentalism.

\section{Independent Variables}

Respondents provided their AGE, SEX (male $=1$, female $=0$ ), total family INCOME for 1981 in categories, level of EDUCATION by degree completed, and rural or URBAN residence (see Table 1 ). Two binary variables $(0,1)$ were constructed to indicate perceptions of social and economic change: STANDARDS, with a value of (1) indicating a perception that general living standards will decrease, and SHORTAGES, with a value of (1) indicating a perception that the United States will face severe resource shortages.

Christian religious preference or no religious belief was coded as a series of dummy variables contrasted with the residual category of mainline Protestant. Orthodox (Greek, Russian, Eastern) Christians and those from outside the Christian religious tradition, including Jews and members of non-western religions, were excluded from the analysis. A series of dummy variables were constructed which represented (a) NONE (no religious preference), (b) CATHOLIC, (c) EVANGELICAL BODIES (including large conservative groups such as Baptists), and (d) FUNDAMENTALIST SECTS (including such small uncompromising groups as Jehovah's Witnesses and Seventh Day Adventists). Each dummy variable was coded (1) and contrasted with Mainline Protestants (0).

A literal interpretation of the Bible and support for the Moral Majority as an organization are often assumed to go hand-in-hand. We constructed a separate item, LITERALISM, measuring agreement with the following statement: The Bible is the actual word of God and is to be taken literally, word for word. Coding for this variable was as follows: Strongly disagree (1); somewhat disagree (2); somewhat agree (3); and strongly agree (4).

\section{Dependent Variables}

Respondents were first asked if they had ever heard or read about an organization called the Moral Majority. Those who had heard of the organization were then asked if they generally approved or disapproved of its goals. As a result, the effects of knowledge of the organization can be separated out from those of approval of its activities or specific issuers associated with it. Knowledge and approval of the Moral Majority is, logically, an intervening variable, dependent with respect to the variables listed above but independent with respect to specific issues.

All respondents, even those with no prior knowledge of the Moral Majority as an organization, were asked to indicate their level of agreement or disagreement with six religio-political issues. Responses were coded into three dependent categories: opposition to the Moral Majority position (OPPONENTS); some support for the Moral Majority position (FELLOW TRAVELERS); and strong support for the position (MORAL MAJORITARIAN). These issues included voluntary public school prayer, the teaching of creationism, military defense spending, gun control, pornography and abortion (see Appendix 
for wording). Each issue has been associated by researchers with the Moral Majority, although some issues originated in the New Political Right.

Using discriminant analyses, each dependent variable is at the nominal level of measurement and their numerical categories are not theoretically or statistically assumed to be ordered on any continuum. Discriminant analysis (Klecka 1980) creates one or more linear combinations of independent variables which best predict the category of the dependent variable in which the case appears. If there is only one significant function, then the relationship between the independent and dependent variables is adequately expressed by a single linear combination of the independent variables. If more than one statistically significant function is found in the analysis, then additional orthogonal continua are needed to account for the relationship. Since our dependent variables have three categories, a maximum of two separate discriminant functions is possible.

The standardized discriminant function coefficients in these analyses, presented in Tables 2 through 5 , are similar to standardized regression coefficients, indicating the relative loading of the independent variables defining the function. The structure coefficients represent the zero-order correlations of the independent variables with the function (Klecka 1980). In path analytic terms, the structure coefficients give the total association, while the standardized discriminant function coefficients estimate direct effects. Given the large sample size, we treated coefficients of .10 or above as substantive.

The group centroids (also presented in Tables 2 through 5) provide a second set of indicators for discriminant analysis. These coefficients indicate the place along the continuum defined by the significant functions where each category of the dependent variable appears. Finally, the canonical correlations provide estimates of how well each function discriminates among dependent variable categories.

\section{Knowledge of and Support for the Moral Majority}

First, what was the extent of knowledge and support for the Moral Majority? Approximately 56 percent of the sample had heard or read of the Moral Majority (see Table 1). Of these, 23 percent (244 respondents) approved of the organization and its general goals. Another 26 percent did not know whether they approved or disapproved, but had heard of the organization. However, most of those who had heard of the Moral Majority "mostly disapproved" of its goals. Out of the total sample of respondents, only 12.8 percent "mostly approved" of the Moral Majority.

Table 2 presents a discriminant analysis of sources of knowledge of and support for the Moral Majority as an organization. In this analysis, knowledge and support are coded into three dependent variable categories: (0) no knowledge of the Moral Majority, (1) know of, but mostly disapprove of the Moral Majority, and (2) know of and support the Moral Majority.

The first function distinguishes those who have not heard of the organization from those who are aware of the Moral Majority but who mostly disapprove of the organization. The dominant indictor of awareness and disapproval is educational level. The second function, which is also significant, primarily distinguishes between respondents who approve and those who disapprove of the Moral Majority. The major factors in this equation are religious preference and belief; Catholics, members of fundamentalist sects and 
Table 1. Knowledge and Approval of the Moral Majority

\begin{tabular}{|c|c|c|c|}
\hline & $\begin{array}{l}\text { Heard/Read } \\
\text { About M. M. }\end{array}$ & $\begin{array}{c}\text { Mostly } \\
\text { Approve }\end{array}$ & $\begin{array}{l}\text { Number of } \\
\text { Respondents }\end{array}$ \\
\hline \multicolumn{4}{|l|}{ Sex } \\
\hline Male & 61.8 & 4.0 & 914 \\
\hline Female & 51.3 & 11.7 & 986 \\
\hline \multicolumn{4}{|l|}{ Religion } \\
\hline Protestant & 57.0 & 11.2 & 987 \\
\hline True Sect & 64.2 & 33.8 & 68 \\
\hline Established Sects & 52.0 & 17.5 & 160 \\
\hline Catholic & 51.0 & 10.0 & 485 \\
\hline None & 68.2 & 6.5 & 93 \\
\hline \multicolumn{4}{|l|}{ Residence } \\
\hline Rural Farm & 51.6 & 12.2 & 288 \\
\hline Rural Non-Farm & 59.6 & 19.3 & 119 \\
\hline Urban (Pop. $<100,000)$ & 50.9 & 11.9 & 877 \\
\hline Urban (Pop. > 100,000) & 67.5 & 13.4 & 613 \\
\hline \multicolumn{4}{|l|}{ Education } \\
\hline Less Than High School & 28.5 & 7.2 & 343 \\
\hline High School & 55.2 & 12.7 & 1151 \\
\hline Junior College & 68.0 & 24.2 & 95 \\
\hline Bachelor's (+) & 87.8 & 16.4 & 311 \\
\hline \multicolumn{4}{|l|}{ Age } \\
\hline $18-24$ & 54.0 & 12.7 & 322 \\
\hline $25-40$ & 65.6 & 14.8 & 623 \\
\hline $41-55$ & 58.3 & 12.6 & 435 \\
\hline $56+$ & 44.9 & 10.5 & 515 \\
\hline Total & 56.2 & 12.8 & 1907 \\
\hline
\end{tabular}

Biblical literalists are most likely to be supportive, while those claiming no religious preference are most likely to disapprove. By and large, this second function appears to tap cultural fundamentalism.

Nonetheless, the emergence of two functions in this analysis indicates that Biblical literalism is not the only source of support for the Moral Majority. This further encourages our search for varying patterns of support across issues.

\section{Stands on the Issues}

The analyses which follow evaluate support of the Moral Majority position on six religio-political issues. Respondents were asked their opinions even if they indicated no prior knowledge of the Moral Majority. Separate indicators of belief in Biblical literalism, 
Table 2. Discriminant Analysis of Approval of the Moral Majority $(\mathrm{N}=1328)$

\begin{tabular}{|c|c|c|c|c|}
\hline \multirow[b]{2}{*}{ Predictors } & \multicolumn{2}{|c|}{ Function 1} & \multicolumn{2}{|c|}{ Function 2} \\
\hline & $\begin{array}{c}\text { Standardized } \\
\text { Coefficient }\end{array}$ & $\begin{array}{l}\text { Structure } \\
\text { Coefficient }\end{array}$ & $\begin{array}{c}\text { Standardized } \\
\text { Coefficient }\end{array}$ & $\begin{array}{l}\text { Structure } \\
\text { Coefficient }\end{array}$ \\
\hline Age & -.082 & -.007 & -.153 & -.156 \\
\hline Sex & .192 & -.015 & .125 & .050 \\
\hline Education & .713 & -.038 & .028 & -.033 \\
\hline Urban & .153 & -.027 & .030 & -.026 \\
\hline Income & .228 & -.050 & .209 & .133 \\
\hline \multicolumn{5}{|c|}{$\begin{array}{l}\text { Religion (Departure from } \\
\text { mainline Protestant) }\end{array}$} \\
\hline True Sect & .248 & -.064 & .576 & .517 \\
\hline Established Sect & .075 & .009 & .217 & .110 \\
\hline Catholic & -.106 & .013 & .067 & .487 \\
\hline None & .122 & .007 & -.267 & -.417 \\
\hline Standard & .092 & -1.000 & .158 & .158 \\
\hline Shortages & -.043 & -.411 & -.026 & .074 \\
\hline Literalism & -.298 & .016 & .557 & .549 \\
\hline Canonical Correlation & \multicolumn{2}{|c|}{$\begin{array}{c}.457(\mathrm{p} 5.001) \\
(88.60 \%)\end{array}$} & \multicolumn{2}{|c|}{$\begin{array}{c}.181(\mathrm{p} 5.001) \\
(11.40 \%)\end{array}$} \\
\hline Group Centroids & $N$ & First Function & Second Fur & action \\
\hline Never Heard & 687 & -.488 & .014 & \\
\hline Mostly Disapprove & 437 & .618 & -.206 & \\
\hline Mostly Approve & 204 & .257 & .386 & \\
\hline
\end{tabular}

knowledge of the Moral Majority, and approval of the Moral Majority were included as independent variables. The direction and placement of the centroids indicates the location and relationship to the discriminant functions (not necessarily linear) of the dependent categories of OPPONENTS, FELLOW TRAVELERS, and MORAL MAJORITARIANS.

\section{Public Schools and the Moral Majority}

Two educational issues are near the heart of the Moral Majority platform on public education and secular humanism: ensuring voluntary prayer and teaching creationism in the public schools. Two significant discriminant functions appear on the issue of school prayer, indicating a more complex support base than religious fundamentalism alone. The first function shows greater support for school prayer among older respondents, members of evangelical and fundamentalist bodies, those who know about and generally 
Table 3. Discriminant Analysis of Support for the Moral Majority Position on Public Prayer and Teaching Creationism

\begin{tabular}{|c|c|c|c|c|c|c|c|c|}
\hline \multirow{3}{*}{$\begin{array}{l}\text { Predictors } \\
\text { Age }\end{array}$} & \multicolumn{4}{|c|}{ Public Prayer } & \multicolumn{4}{|c|}{ Creationism } \\
\hline & \multicolumn{4}{|c|}{$\begin{array}{cc}\text { Function } 1 & \text { Function } 2 \\
\text { [Standardized Coefficient] }\end{array}$} & \multicolumn{4}{|c|}{$\begin{array}{cc}\text { Function } 1 & \text { Function } 2 \\
\text { [Standardized Coefficient] }\end{array}$} \\
\hline & .537 & $(.551)^{1}$ & -.017 & $(-.023)$ & .020 & $(.050)$ & .220 & $(.293)$ \\
\hline Sex & .073 & $(-.044)$ & .112 & $(.105)$ & -.168 & $(-.202)$ & -.110 & $(-.235)$ \\
\hline Education & -.189 & $(-.494)$ & .133 & $(-.013)$ & -.079 & $(-.226)$ & -.108 & $(-.422)$ \\
\hline Urban & .062 & $(-.118)$ & -.467 & $(-.410)$ & -.067 & $(-.169)$ & -.175 & $(-.267)$ \\
\hline Income & -.127 & $(-.304)$ & .153 & $(.098)$ & .051 & $(-.093)$ & -.099 & $(-.288)$ \\
\hline \multicolumn{9}{|l|}{ Religion (Departure from } \\
\hline Fundamentalist Sects & .145 & $(.202)$ & -.397 & $(-.511)$ & .271 & $(.419)$ & -.243 & $(-.298)$ \\
\hline Evangelical Bodies & .266 & $(.290)$ & .342 & $(.264)$ & .174 & $(.232)$ & .270 & $(.266)$ \\
\hline Catholic & .106 & $(-.010)$ & .173 & $(.172)$ & .153 & $(-.017)$ & .238 & $(.269)$ \\
\hline None & -.031 & $(-.220)$ & .144 & $(.081)$ & .078 & $(-.127)$ & -.273 & $(-.392)$ \\
\hline Standard & .011 & $(-.012)$ & .134 & $(.218)$ & .026 & $(-.006)$ & -.143 & $(-.090)$ \\
\hline Shortages & .000 & $(.047)$ & .311 & $(.360)$ & -.110 & $(-.049)$ & .291 & $(.286)$ \\
\hline Approve M.M. & .344 & $(.171)$ & .181 & $(-.117)$ & .396 & $(.448)$ & -.092 & $(-.359)$ \\
\hline Knowledge & .389 & $(.439)$ & .576 & $(.413)$ & -.011 & $(.088)$ & .506 & $(.720)$ \\
\hline Literalism & .462 & $(.667)$ & -.359 & $(-.271)$ & .803 & $(.852)$ & .007 & $(.212)$ \\
\hline Canonical Correlation & $\begin{array}{r}.419 \\
(90.4\end{array}$ & $\begin{array}{l}\leq .001) \\
\%)\end{array}$ & $\begin{array}{r}.148 \\
(9.5\end{array}$ & $\begin{array}{l}(\mathrm{p} \leq .01) \\
\%)\end{array}$ & .518 & $\begin{array}{l}\leq 5.001) \\
5 \%)\end{array}$ & $\begin{array}{l}.229 \\
(13.1\end{array}$ & $\begin{array}{l}(\mathrm{p} \leq .001) \\
4 \%)\end{array}$ \\
\hline Group Centroids & $N$ & Func & on 1 & Function 2 & $N$ & Function 1 & & Function 2 \\
\hline Opponents & 749 & -.3 & & .059 & 476 & -.590 & & -.297 \\
\hline Fellow Travelers & 438 & .4 & & .020 & 640 & .138 & & .257 \\
\hline Moral Majoritarians & 78 & .8 & & -.778 & 144 & 1.345 & & -.136 \\
\hline
\end{tabular}

${ }^{1}$ Structure Coefficient

approve of the Moral Majority, and Biblical literalists. Higher income and education levels predict opposition to public school prayer on this first function. Note that on this function FELLOW TRAVELERS are positioned closely to the MORAL MAJORITARIANS in their support of this issue.

On the second function, the FELLOW TRAVELERS group centroid shifts to a position closer to the OPPONENTS. FELLOW TRAVELERS resemble opponents of school prayer and are distinguished from MORAL MAJORITARIANS by higher education and income, membership in evangelical bodies, and concern about shortages and standards of living. Males, Catholics, and those with no religious preference are also less likely to support the Moral Majority on the school prayer issue. Interestingly, resistance to the Moral Majoritarian stance is influenced by the knowledge variable, indicating that having heard or read of the Moral Majority predicts disagreement with its position on school prayer. Support for the Moral Majoritarian position is predicted by rural residence, membership in fundamentalist sects and Biblical literalism, again a cultural fundamentalist pattern. 
We next assessed support for the Moral Majority position on the teaching of creationism in public schools. This analysis also yields two significant discriminant functions (Table 3). The first, which indicates support for the Moral Majority position, is predominately affected by Biblical literalism and approval of the Moral Majority. Support is also predicted by membership in evangelical bodies and fundamentalist sects. Gender is the only other significant demographic factor, with females somewhat more opposed than males to the teaching of creationism once other factors are controlled.

The second discriminant function reveals a significant $(\mathrm{p} \leq .001)$ orthogonal linear combination of the independent variables. The group centroids describe MORAL MAJORITARIANS as similar to OPPONENTS, indicating that these two groups are undifferentiated on this function. FELLOW TRAVELERS are older respondents, Catholics, evangelicals, persons concerned about economic shortages, and respondents who have knowledge of the Moral Majority. It is interesting to note that the number of respondents represented in this group is considerably greater than in the other public school issue (640 respondents compared to 438 FELLOW TRAVELERS for public school prayer). The second function suggests that FELLOW TRAVELERS who are not closely aligned with fundamentalism, Biblical literalism or approval of the Moral Majority provide some support for the Moral Majoritarian stand on this particular school issue.

Overall, however, both of these public school items yield strong first discriminant functions (explaining 42 to 52 percent of the variance) with Biblical literalism and approval of the Moral Majority as major predictors of a Moral Majoritarian stance. The demographic variables are generally weaker predictors, but their coefficients suggest that the elderly, low income, poorly educated and rural respondents align with the Moral Majority on this cluster of educational issues. This may represent a status politics phenomenon. If so, however, it is exceedingly weak in comparison to cultural effects.

\section{Defense Spending and Gun Control}

Males and supporters of the Moral Majority as an organization are significantly more likely to support increases in defense spending and to oppose gun control. But substantive differences are evident on the issues. Table 4 shows the two significant discriminant functions generated for defense spending. On the first function, the single most important factor predicting support is Biblical literalism. Males also support increased spending, as do those who indicate less concern about future deterioration of living standards and shortages. The first function strongly differentiates MORAL MAJORITARIANS from both OPPONENTS and FELLOW TRAVELERS.

On the second military spending function, the FELLOW TRAVELERS realign with MORAL MAJORITARIANS. Support is predicted by age, gender (male), higher income, a perception that resources and standards of living will erode in the future, and knowledge and approval of the Moral Majority. In contrast, higher education levels, membership in fundamentalist sects and no religious preference predict opposition to increased military spending. Unlike the first equation, Biblical literalism has no consistent effect on this function, but knowledge and approval of the Moral Majority are significant predictors of support. This second function highlights the divergence of Biblical literalists and members of fundamentalist sects from the Moral Majority platform on specific issues. Moreover, the 
Table 4. Discriminant Analysis of Support for the Moral Majority Position on Military Defense and Gun Control

\begin{tabular}{|c|c|c|c|c|c|c|c|c|}
\hline \multirow{3}{*}{$\frac{\text { Predictors }}{\text { Age }}$} & \multicolumn{4}{|c|}{ Military Defense } & \multicolumn{4}{|c|}{ Gun Control } \\
\hline & \multicolumn{4}{|c|}{$\begin{array}{cc}\text { Function } 1 & \text { Function } 2 \\
\text { [Standardized Coefficient] }\end{array}$} & \multicolumn{4}{|c|}{$\begin{array}{cc}\text { Function } 1 & \text { Function } 2 \\
\text { [Standardized Coefficient] }\end{array}$} \\
\hline & -.090 & $(-.063)^{1}$ & .334 & $(.388)$ & .143 & $(.158)$ & .38 & $(.330)$ \\
\hline Sex & .123 & $(.103)$ & .334 & $(.293)$ & .702 & $(.709)$ & .02 & $(.050)$ \\
\hline Education & -.028 & $(-.114)$ & -.211 & $(-.246)$ & -.121 & $(.008)$ & -.27 & $(-.166)$ \\
\hline Urban & .192 & $(.067)$ & .050 & $(-.053)$ & -.560 & $(-.537)$ & .17 & $(.245)$ \\
\hline Income & .015 & $(-.054)$ & .537 & $(.404)$ & .146 & $(.192)$ & .14 & $(.132)$ \\
\hline \multicolumn{9}{|l|}{ Religion } \\
\hline Fundamentalist Sects & -.151 & $(.106)$ & -.163 & $(-.142)$ & .117 & (.137) & -.21 & $(-.359)$ \\
\hline Evangelical Bodies & -.050 & $(.047)$ & .061 & $(.053)$ & .072 & $(.048)$ & .34 & $(.249)$ \\
\hline Catholic & .126 & $(.049)$ & .086 & $(.130)$ & -.195 & $(-.271)$ & .05 & $(.024)$ \\
\hline None & .122 & $(.007)$ & -.207 & $(-.320)$ & -.047 & $(-.021)$ & .22 & $(.233)$ \\
\hline Standard & -.205 & $(-.321)$ & .264 & $(.327)$ & .010 & $(.041)$ & .36 & $(.332)$ \\
\hline Shortages & -.290 & $(-.353)$ & .165 & $(.252)$ & .004 & $(-.032)$ & -.04 & $(.091)$ \\
\hline Approve M.M. & .062 & $(.173)$ & .403 & $(.194)$ & .164 & $(.289)$ & .31 & $(.134)$ \\
\hline Knowledge & -.164 & $(-.019)$ & .545 & $(.360)$ & -.242 & $(-.314)$ & .23 & $(.038)$ \\
\hline Literalism & .965 & $(.827)$ & .098 & $(.207)$ & -.077 & $(.008)$ & -.65 & $7 \quad(-.590)$ \\
\hline Canonical Correlation & \multicolumn{2}{|c|}{$\begin{array}{c}.239(\mathrm{p} \leq .001) \\
(70.44 \%)\end{array}$} & \multicolumn{2}{|c|}{$\begin{array}{l}.158(\mathrm{p} \leq .01) \\
(29.56 \%)\end{array}$} & \multicolumn{2}{|c|}{$\begin{array}{l}.351(\mathrm{p} \leq .001) \\
(89.13 \%)\end{array}$} & \multicolumn{2}{|c|}{$\begin{array}{l}.130 \\
(10.87 \%)\end{array}$} \\
\hline Group Centroids & $N$ & Function 1 & & nction 2 & $N$ & Functic & & Function 2 \\
\hline Opponents & 449 & -.130 & & 280 & 633 & -.37 & & -.050 \\
\hline Fellow Travelers & 636 & -.058 & & 153 & 474 & .26 & & .146 \\
\hline Moral Majoritarians & 181 & .500 & & 128 & 161 & .57 & & -.241 \\
\hline
\end{tabular}

${ }^{1}$ Structure Coefficient

support of high-income respondents for increased defense spending contradicts both the status politics and cultural fundamentalism theories.

The gun control issue is dominated by a single significant equation, with males and rural respondents showing strong opposition to legal control (Table 4). Membership in fundamentalist sects, approval of the Moral Majority, age and higher income levels also load on this function. Literalism is unrelated to support. Catholic religious preference predicts some level of opposition to the Moral Majority platform, as does knowledge of the Moral Majority. This function yields a linear assessment of support for the Moral Majority position.

The lack of a relationship between Biblical literalism and one's position on gun control and the opposition of members of fundamentalist sects to increased military spending revealed in the second function suggests that these are multidimensional, often secular issues. Where knowledge and approval of the Moral Majority are significant factors, the Biblical literalism variable shows no effects, and vice versa. Moreover, gender shows a consistent pattern; males support defense increases and oppose gun control. Knowledge of the Moral Majority is not a straightforward indicator of opposition to gun control. 
Table 5. Discriminant Analysis of Support for the Moral Majority Position on Pornography, Abortion

\begin{tabular}{|c|c|c|c|c|c|c|c|c|}
\hline \multirow{3}{*}{$\begin{array}{l}\text { Predictors } \\
\text { Age }\end{array}$} & \multicolumn{4}{|c|}{ Pornography } & \multicolumn{4}{|c|}{ Abortion } \\
\hline & \multicolumn{4}{|c|}{$\begin{array}{cc}\text { Function } 1 & \text { Function } 2 \\
\text { [Standardized Coefficient] }\end{array}$} & \multicolumn{4}{|c|}{$\begin{array}{c}\text { Function } 1 \quad \text { Function } 2 \\
\text { [Standardized Coefficient] }\end{array}$} \\
\hline & .643 & $(.627)^{1}$ & -.122 & $(-.239)$ & -.142 & $(-.173)$ & .378 & $(.380)$ \\
\hline Sex & -.418 & $(-.445)$ & -.153 & $(-.129)$ & -.161 & $(-.220)$ & -.143 & $(-.118)$ \\
\hline Education & -.034 & $(-.300)$ & .183 & $(.238)$ & .031 & $(-.120)$ & -.304 & $(-.146)$ \\
\hline Urban & .017 & $(-.116)$ & .404 & $(.433)$ & .020 & $(-.059)$ & .417 & $(.341)$ \\
\hline Income & .109 & $(-.063)$ & .006 & $(.034)$ & -.137 & $(-.184)$ & .496 & $(.377)$ \\
\hline \multirow{2}{*}{\multicolumn{9}{|c|}{ Religion (Departure from }} \\
\hline & \multicolumn{8}{|c|}{ Mainline Protestant) } \\
\hline Fundamentalist Sects & .078 & $(.155)$ & .169 & $(.174)$ & .157 & $(.225)$ & .162 & $(.210)$ \\
\hline Evangelical Bodies & .363 & $(.087)$ & .304 & $(.311)$ & .215 & (.193) & .161 & $(.200)$ \\
\hline Catholic & .180 & $(.095)$ & .076 & $(-.072)$ & .580 & $(.477)$ & -.139 & $(-.260)$ \\
\hline None & -.112 & $(-.322)$ & .399 & $(.356)$ & -.029 & $(-.229)$ & .190 & $(.113)$ \\
\hline Standard & -.015 & $(-.024)$ & -.485 & $(-.495)$ & -.019 & $(-.028)$ & -.142 & $(-.202)$ \\
\hline Shortages & -.004 & $(.031)$ & -.106 & $(-.313)$ & -.007 & $(.032)$ & -.196 & $(-.289)$ \\
\hline Approve M.M. & .325 & $(.175)$ & .149 & $(.289)$ & .622 & $(.595)$ & -.188 & $(.008)$ \\
\hline Knowledge & .315 & $(.348)$ & -.239 & $(-.358)$ & .102 & $(-.023)$ & -.357 & $(-.188)$ \\
\hline Literalism & .475 & $(.590)$ & .340 & $(.203)$ & .429 & $(.509)$ & .492 & $(.404)$ \\
\hline Canonical Correlation & \multicolumn{2}{|c|}{$\begin{array}{l}.498(\mathrm{p} \leq .001) \\
(95.18 \%)\end{array}$} & \multicolumn{2}{|c|}{.128 (4.82\%) } & \multicolumn{2}{|c|}{$\begin{array}{c}.268(\mathrm{p} \leq .001) \\
(77.22 \%)\end{array}$} & \multicolumn{2}{|c|}{$\begin{array}{l}.150(\mathrm{p} \leq .01) \\
(22.78 \%)\end{array}$} \\
\hline Group Centroids & $N$ & Functio & & unction 2 & $N$ & Functio & & unction 2 \\
\hline Opponents & 439 & -.704 & & .150 & 948 & -.15 & & .028 \\
\hline Fellow Travelers & 506 & .135 & & -.175 & 228 & .295 & & -.264 \\
\hline Moral Majoritarians & 354 & .738 & & .057 & 96 & .769 & & .360 \\
\hline
\end{tabular}

${ }^{1}$ Structure Coefficient

\section{Pornography and Abortion}

In these two analyses, the first function identifies linear support for Moral Majority positions on pornography and abortion. The second function differentiates the FELLOW TRAVELERS, realigning them with OPPONENTS. Opposition to pornography is predicted on the first function by age, sex, literalism, knowledge and approval of the Moral Majority. Women, the elderly and Biblical literalists are more likely to support the Moral Majority position on pornography while persons with no religious preference are likely to oppose it.

Two aspects of the pornography equations are important. First, the Fellow Travelers and Moral Majoritarians have substantially increased in numbers to 506 and 354 respondents, respectively. Second, the pornography issue, in its contemporary state, has drawn support not only from the New Religious Right, but also from feminist and other political groups which identify pornography as violence against women rather than as an issue of sexual morality. Thus, the first function may combine two distinct support populations. The second function, with a canonical correlation of .128, barely misses the .05 level of significance. However, it does suggest that Fellow Travelers are distinguished from Moral 
Majoritarians through a number of demographic factors, including age, sex, education, urban residence and sectarianism.

On the issue of abortion, women are more likely than men to support the position of the Moral Majority, when other factors are controlled (Table 5). Biblical literalism, approval of the Moral Majority, Catholic religious preference, sectarian membership, age and income are also substantively significant. Younger respondents and those with lower income levels oppose the Moral Majority position. The number of OPPONENTS has increased substantially. More respondents (948) oppose the Moral Majority on abortion than on any other issue included in the analysis.

The second function primarily differentiates the FELLOW TRAVELERS as a group. Biblical literalism, sect membership, no religious preference, urban residence, more advanced age and higher incomes distinguish strong from more marginal supporters. Women, those with lower educational levels, Catholics, respondents who are concerned about shortages and eroding standards of living, as well as those without knowledge of the Moral Majority, are more likely to be FELLOW TRAVELERS. The analysis suggests that the Moral Majority stance does not represent any clear status group on the issue of abortion. This second function accounts for fifteen percent of the variance in abortion attitudes, highlighting the variability in support patterns.

\section{Conclusions}

Support for the Moral Majority per se is given by only 12 percent of the sample, which is less than that for specific religious and political issues associated with the Moral Majority platform. At the time of the survey, the position of the Moral Majority was "strongly" supported by the largest percentage of respondents on the issues of pornography (27 percent), military spending (15.4 percent), gun control (14.3 percent) and ranged downward to only 7.5 percent strong approval of their abortion stance. Knowledge and approval of the Moral Majority are influenced by Biblical literalism and fundamentalist or evangelical religious preferences. The primary predictor of approval of the Moral Majority is knowledge of the organization. ${ }^{1}$

While knowledge and approval predict political and religious attitudes, they do have independent effects. Thus, they are separate dimensions. Support for the Moral Majority loads significantly on all first functions except military defense spending. Biblical literalists support the Moral Majority as an organization, but differ with it on specific issues, especially gun control. Thus, not all Moral Majoritarians are Biblical literalists, and not all Moral Majoritarians ( or literalists)have similar views on specific issues.

Overall, the religious bases of support for political stands taken by the Moral Majority organization are clearest on the public school issues of creationism and voluntary prayer. The remaining issues draw support from more diverse demographic and interest groups. Males supported military defense spending and unrestricted access to guns; females were against pornography and abortion. Urban, highly educated and high income respondents took conservative stances on some items, particularly abortion and military defense; yet persons in these same categories opposed government restriction of pornography. These patterns vary, and support for the Moral Majority per se by these same groups is weak. Other interest groups, including the gun lobby, business interests in metropolitan areas, and perhaps even feminists advocating restriction of pornography, seem to shift from pro- to anti-Moral Ma- 
jority stances on specific issues rather than accepting its entire platform. To the extent that there is a single unifying basis of support across issues, it appears to rise from membership in conservative and literalist religious groups. However, shifting interest group coalitions are evidently the driving force behind the resurgence of political conservatism.

Support for the Moral Majority as an organization is far weaker and more varied than its leaders would have us believe. Its pronouncements on religio-political issues appear to have had little effect on stands taken on issues of military defense, gun control, pornography and abortion. Support from cultural fundamentalists and the dispossessed is most evident on the educational issues of school prayer and teaching creationism.

Because these support patterns vary, it is empirically questionable to combine separate items from the Moral Majority platform into a single scale measuring support for the Moral Majority. It is also politically inadvisable to assume that religious sectarianism and Biblical literalism are the sole cornerstones of support for Moral Majoritarian or New Religious Right issues among the general public.

Theories in the sociology of religion which seek to account for a rise in conservatism and support for political activism among the economically or culturally threatened must be refined. How can we account for the positions of the economically privileged on specific issues, or even their unpredicted support for the Moral Majority organization? What accounts for the gender differences in support for military defense spending, gun control, abortion and pornography? Are these mere reflections of sex role socialization, or do they identify some fundamental difference in moral frameworks between women and men which go beyond conservative or fundamentalist religiosity? Finally, will the alignments indicated by these issue-specific analyses add to the conservative religious baseline of support for groups such as the Moral Majority or the Liberty Foundation? Or will the shifting sands of interest group politics erode these organizations in the future? An expanded view of organizational platforms and support systems may help to answer these questions in the decades ahead.

\section{Appendix \\ Questionnaire Items for Moral Majority Issues \\ 1982 Nebraska Annual Social Indicators Survey}

Now I would like to ask you some questions about some current issues. Do you strongly agree, agree, disagree or strongly disagree* with each of the following statements:

The public schools should conduct prayers as part of their official business.

The government should do whatever is necessary to eliminate all pornography such as X-rated movies and pornographic bookstores.

The United States should increase spending for military defense.

The country would be better off if we had strict gun control laws.**

The public schools should teach students that the universe was created by God as described in the Bible.

Whether to have an abortion is strictly a private decision, which the government should not try to regulate in one way or another.**

\footnotetext{
${ }^{*}$ Discriminant categories were coded: strongly agree (2), somewhat agree (1), somewhat disagree, strongly disagree (0).

**Responses to these questions were reversed for analysis.
} 


\section{Acknowledgments}

We would like to thank Harry Crockett and Nicholas Babchuk, for helpful editing of an earlier draft, and Philip B. Coulter, Director, Center for Administrative and Policy Studies, University of Alabama, for the use of the Christian Right questions from the statewide Alabama Capstone Poll (1981).

\section{Note}

1. This may be an artifact. Only those who know about the Moral Majority are asked if they approve of the organization.

\section{References}

Bell, D.P. 1963. “The Dispossessed.” Pp. 1-45 in The Radical Right, edited by D. Bell. New York: Doubleday.

Booth, A., L. White, D.R. Johnson and J. Lutze. 1980. “Combining Contract and Sociological Research: The Nebraska Annual Social Indicators Survey." The American Sociologist 15: 32-48.

Brown, R.M. 1986. "The New Religious Right and the Need for a Moral Minority." Unpublished manuscript, University of Nebraska, Lincoln.

“Falwell Rechristens His Majority." Time, January 13, 1986, p. 25.

Gannon, T.M. 1981. "The New Christian Right in America as a Social and Political Force." Archives de Sciences Sociales des Religions 52(1): 69-83.

Granberg, D. 1981. “The Abortion Activists.” Family Planning Perspectives 13: 157-163.

Gusfield, J.R. 1966. Symbolic Crusade: Status Politics and the American Temperance Movement. Urbana: University of Illinois Press.

Hadden, J.K. and C. Swann. 1981. Prime Time Preachers: The Rising Power of Televangelism. Reading, MA: Addison-Wesley.

Harper, C.L. and K. Leicht. 1982. "Religious Belief, Religious Identity, and Political Values: The Social Meaning of the New Religious Right." Paper presented at the annual meeting of the Society for the Scientific Study of Religion, Providence, RI.

. 1984. “Explaining the New Religious Right: Status Politics and Beyond." Pp. 101-112 in New Christian Politics, edited by D.G. Bromley and A.D. Shupe. Macon, GA: Mercer University Press.

Hill, S.S. and D.E. Owen. 1982. The New Religious Right in America. Nashville, TN: Abingdon.

Himmelstein, J.L. 1983. “The New Right.” Pp. 13-30 in The New Christian Right: Mobilization and Legitimation, edited by R.C. Liebman and R. Wuthnow. New York: Aldine.

Jorstad, E. 1981. Evangelicals in the White House: The Cultural Maturation of Born Again Christianity, 1960-1981. New York: Edwin Mellon Press.

Klecka, W.R. 1980. Discriminant Analysis. Beverly Hills: Sage.

Lipset, S.M. 1963. “The Source of the 'Radical Right'.” Pp. 307-371 in The Radical Right, edited by D. Bell. New York: Doubleday.

Lipset, S.M. and E. Raab. 1978. The Politics of Unreason. 2nd ed. New York: Harper. .1981. "The Election and the Evangelicals." Commentary 71: 25-31.

Marty, M.E. 1985. “The Old New Religions and the New Old Religions.” The Nebraska Humanist 8: 9-15. 
Moore, H.A. 1982. Designs, Procedures, Instruments and Forms for the 1982 Nebraska Social Indicators Survey. Lincoln: Bureau of Sociological Research, University of Nebraska.

Page, A.L. and D.A. Clelland. 1978. "The Kanawha County Textbook Controversy: A Study in the Politics of Life Style Concern." Social Forces 57: 265-28 1.

Plowman, Edward E. 1979. “Is Morality All Right?” Christianity Today 23: 76-85.

Rubin, Gayle. 1984. "Thinking Sex: Notes for a Radical Theory of the Politics of Sexuality." In Pleasure and Danger: Exploring Female Sexuality, edited by C. Vance. Boston: Routledge \& Kegan Paul.

Shupe, A.D. and W.A. Stacey. 1982. "Sentiments for the Moral Majority in the Dallas-Fort Worth Metropolex." Paper presented to the Association for the Sociology of Religion, Providence, RI. . 1983. “The Moral Majority Constituency." Pp. 103-115 in The New Christian Right: Mobilization and Legitimation, edited by R.C. Liebman and R. Wuthnow. New York: Aldine.

1984. "Public and Clergy Sentiments Toward the Moral Majority: Evidence From the DallasFort Worth Metroplex." Pp. 91-100 in New Christian Politics, edited by D.G. Bromley and A.D. Shupe. Macon, GA: Mercer University Press.

Simpson, J.H. 1983. "Moral Issues and Status Politics." Pp. 187-205 in The New Christian Right: Mobilization and Legitimation, edited by R.C. Liebman and R. Wuthnow. New York: Aldine.

. 1985. "Status Inconsistency and Moral Issues." Journal for the Scientific Study of Religion 24: 155-162.

Speer, J.A. 1984. "The New Christian Right and Its Parent Company: A Study in Political Contrasts." Pp. 40 in New Christian Politics, edited by D.G. Bromley and A.D. Shupe. Macon, GA: Mercer University Press.

Tamney, J.B. and S.D. Johnson. 1982. “The Moral Majority in Middletown." Paper presented at the Annual Meeting of the Society for the Scientific Study of Religion.

Viguerie, R.A. 1981. The New Right: We're Ready to Lead. Falls Church, VA: The Viguerie Company.

Whitt, H.P. and H.M. Nelsen. 1975. "Residence, Moral Traditionalism and Tolerance of Atheists." Social Forces 54: 328-340.

Wood, M. and M. Hughes. 1984. "The Moral Basis of Moral Reform: Status Discontent vs. Culture and Socialization as Explanation of Anti-pornography Social Movement Adherence." American Sociological Review 49: 86-99.

Yinger, J.M. and S.J. Cutler. 1982. “The Moral Majority Viewed Sociologically.” Sociological Focus 15: 489-506.

Zurcher, L.A. and R.G. Kirkpatrick. 1976. Citizens for Decency: Anti-Pornography Crusades as Self-Defense. Austin: University of Texas Press. 